\author{
Natakorn Satienchayakorn \\ Thammasat University, Thailand \\ Pattamawan Jimarkon \\ University of Stavanger, Norway
}

\title{
DECONSTRUCTION OF THE DISCOURSE OF FEMININITY: A CASE OF THAI GIRLS' SCHOOLS
}

Summary. The study investigates the construction of femininity ideologies of girls-only school websites in Thailand and deconstructs them for analysis at the lexical level. Ideological beliefs underlying the custom of upbringing of young women in Thai cultural contexts are the focus of investigation. We pay a particular attention to how the schools communicate their key messages of vision, mission, core values, and about us on their websites and conduct a corpus-driven discourse analysis on the data. Findings from running tests of frequency and collocation reveal the traits of femininity constructed in the discourse, built the praising of obedience, submissiveness and lady-like features. We conclude that benevolent sexism is a common cultural practice evident in educational institutions.

Keywords: corpus analysis; education; gender; sexism.

\section{Introduction}

Thailand, a middle-income country situated in Southeast Asia, is a maledominated society (Persaud, 2005) with visible gaps on participation remuneration and advancement. Only in 1997 were women in Thailand granted equal rights such as assuming an executive role, representing in Thailand's national parliament, being in the police force, and serving in the military by constitution (Romanow, 2012). More subtle bias, prejudice, and discrimination towards women are addressed (Jarunratanakul \& Jinchang, 2018) in several studies (Bui \& Permpoonwiwat, 2015; Chinlumprasert, 2001; Ford \& Kittisuksathit, 1996; Isaraphakdi, 2000; Jarunratanakul \& Jinchang, 2018). Although we see more and more Thai women actively engaging in productive employment; especially at the management level, these women have received lower pay than men (Bui \& Permpoonwiwat, 2015) and have constantly experienced negative stereotypes at the workplace. The stereotypes include being incompetent at jobs, being overly sensitive, being indecisive, lacking 
confidence and ambition. Biases at work, both unconscious or not, put an unneeded thumb on their career performance and aspirations (Jarunratanakul \& Jinchang, 2018). Those negative experiences have resulted in their decrease in confidence when advocating for their pay increase.

Such discriminatory practices have also been extended to domestic relations. The awareness of gender roles operates the mechanism of how a relationship starts, proceeds and ends. In the modern dating scene, while women are now known to initiate a date and express how they feel first (Chinlumprasert, 2001), Thai women are not allowed to do so. Further, once they are in heterosexual relationships, they are subject to being faithful and forgiving for his meanderings. On the other hand, their male counterparts are free to enjoy multiple partners because doing so makes them real men. Premarital sex, to Thai men, is seen as experimentation so they tend to have casual sex with others yet, it is acceptable for them to do so (Isaraphakdi, 2000). The same cannot be said about Thai women or they will be judged harshly by the society (Ford \& Kittisuksathit, 1996). For many centuries, Thai women are expected to take up the working roles as a good wife and mother, which means loyalty and obedience to the husband and endless devotion as a loving caregiver to her children (Prabjandee, 2014).

Despite being granted equal rights in 1997, modern Thai women are still faced with the expectations to possess these qualities. Thailand appears to be a globalized and modern society on the outlook but the discrimination against women has proven to be apparent. Schools are often the first place where female students experience such discriminations as social ideologies are well embedded in different discourses such as teaching materials and school policies (Hawkins \& Norton, 2009). Specifically, school promotional methods and propagandas are ways that schools position themselves to the public. Like the rest of the world, nowadays, girls and boys in Thailand receive equal education but the ways they are treated at school are still strikingly different in term of gender subjectivity. For example, boys should be gentlemen and girls should be soft and sensitive. Therefore, it is worthy of investigating to unveil the ideologies engrained in website texts that might display the construction of identities of female adolescents. We paid a particular attention to how the girls' schools communicated their messages on their 
websites in the particular sections - vision, mission, core values, and about us because they represented schools' images, moralities, goals, and identities (Bingöl et al., 2013; Kaptein, 1998; Papulova, 2014; Ruvio, Rosenblatt \& Hertz-Lazarowitz, 2010). We employed a 'Corpus-driven approach' in the hope to locate forces of ideologies in Thai girls' school websites from analyzing lexical units in the texts. The data of this study was restricted to written texts, purposively obtained from, and limited to 77 girls' schools nationwide in Thailand. This corpus analysis will bring about a better understanding of ideological agendas in educational settings by answering the two research questions:

1. What were the characteristics of Thai girls' lexically prescribed in girl schools' websites?

2. What underlying ideologies were constructed in the identities of Thai female adolescents in the discourses?

\section{Literature Review}

We argue that to combat discriminations against women, one needs the intellectual weapon of education (Athamneh \& Benjamin, 2019). During the process of forming thoughts to initiate this study, we saw that it also worked the other way around, that is, education is created to foster discriminations. The study wishes to make visible the formal practice of gender bias that is ever long-standing by using a rigorous tool to deconstruct this bias into smaller units of words. In this section, to start with, we describe the feminist movements in Thailand to establish the context of the study regarding oppression of Thai women. Then, we shall move on to education for Thai girls and how girls' schools communicate their identities through school websites through corpus analyses of lexical items. Lastly, we will locate where our present study stands in the scholastic literature. 


\section{The Feminist Movements in Thailand}

With the awareness of such discrimination in the male-domineering world, feminist movements (Mills \& Mullany, 2011), Rampton (2015) advocates for acceptance of dignity, intelligence, and basic human potential of the female to challenge traditional gender norms. Thailand has also so seen a continuous run of feminist movements. Somswasdi (2003, pp. 2-6) outlines several policy reforms for Thai women such as the rights for the marriage property ownership and the prevention of double marital registration. Nevertheless, the aforementioned reforms were written texts kept as policies. In practice, none of them is strictly practiced (Bui \& Permpoonwiwat, 2015; Chinlumprasert, 2001; Ford \& Kittisuksathit, 1996; Isaraphakdi, 2000; Jarunratanakul \& Jinchang, 2018).

In 1997, Thai women's voices were heard through an advocacy campaign to fight against gender equality at the policy-making level which resulted an inclusion of the clause "Men and women are equal" in the 1997 Constitution (Tantiwiramanond \& Pandey, 2008). The 2008 study suggests that Thai women had played several key roles for years but were biased from public and political decision-making roles. It asserts that their opinions and interests were essentially disregarded. Understanding the feminist perspective and recognizing oppression is not enough. Education has been used as a tool to foster desirable ideologies for a long time. In the same way, one needs education as a weapon to fight all discrimination against them (Athamneh \& Benjamin, 2019). We, then, argue that it would be insightful to start examining the issue in the education context to see if these ideological empowerments currently are engrained in the construction of identities of female adolescents in girls' schools in Thailand. In the next section we will provide an overview of education for women in Thailand.

\section{Education for Girls}

From ancient time to the reign of Rama III (during 1824-1851), and to a period of pre-reformation (1851-1868), only the male royals and highborn were allowed to study. Education, with moral, intellectual and cultural topics, took 
place at the temple and performed by monks, all male. Meanwhile, Thai women were trained at home informally or at a royal palace to become good wives and mothers (Onozawa, 2001) on their domestic duties and house chores. The first girls' school was a private or preparatory school called Wattana Wittaya Academy or Kullasatri Wang Lang in Thai. It was found in 1874 (Costa, 1997) as a finishing school, training girls to possess social graces and traditional rites, skills necessary for girls at that time. Later, Thai political revolution occurred in 1932 resulting from the influence of western nations. That is, the revolution did not only bring democracy to Thailand, but also a rise of the Western education philosophy which provided equal access to education for both girls and boys. As a result, Thai girls were allowed to attend schools and study, and therefore could compete with men for better careers (Robkob, 2008). After 1965 , there emerged more co-ed schools. In $1980,42 \%$ of female students were enrolled at primary and secondary levels. Later, in the same year, the percentage increased to $48 \%$ (Jimenez et al., 1988).

\section{Girls' Schools and School Websites}

There had been a debate in Thailand as to which mixed-public or private or preparatory schools were better for parents to enroll their children. Later, it was confirmed that students whose GPA scores were high tended to choose public schools, but the results also suggested that private or preparatory schools were more efficient and effective in enhancing students' academic achievements than mixed public schools (Jimenez et al., 1988). However, Regoli (2019) pointed out several issues in the mixed schools as well. For example, as the children enter adolescence, physical differences become apparent and cause distraction resulting in intimate relationships at an early age. In addition, when students learned in mixed classrooms, male students were typically seen as tough, strong, and independent. Meanwhile, female students were viewed in the opposite way. This is a traditional Thai stereotype towards Thai female students that still holds true. As a result, girls' schools in Thailand are places where Thai girls perform well academically, and at the same time, can behave well (Regoli, 2019).

Like any other enterprise, well-maintained school websites, especially 
private ones, can help gain a competitive advantage. Their appearance and texts work as a great tool to provide useful information about the school and convince parents that the school offers the best education while taking good care of their children.

This was supported by Slattery et al. (2019)'s study. That is, if the website presented interesting information such as product models and details, the website's visitors tended to spend more time here. In line with Hackett et al. (2005)'s study, governmental and public sectors tended to use websites to promote their good images to the public. However, the website's visitors would be easily manipulated if the website presented manipulative discourses (Ault et al., 2017). There is no exception in a school's website. While there are sections which provide useful for visitors; for examples, news, admissions, event information, and academic programs, the following sections could provide manipulative discourses as several studies have suggested. That is, vision section presents imaginative a company's strong and powerful image which manipulates the audiences' mental cognition (Ruvio et al., 2010) and uses mission section as a strategy to achieve the vision (Papulova, 2014). Core values section shows a company's trustworthiness, morality, respect, and responsibilities to the public (Kaptein, 1998) and about us section expresses the organization's unique story, attribution, and identity which a company would like to share with the world (Bingöl et al., 2013). Given the characteristics of vision, mission, core values, and about us in Thai girl school's websites, we see this as contingent data, in the sense that it presents not to convince the viewers to believe in the messages, but to confirm the positioning of the schools towards how ideal characteristics of Thai female students are perceived.

\section{Corpus Linguistics Analyses in Thai Context}

Corpus linguistics has been generally popular to reveal language use and power between two genders (male and female) in difference discourses (Daniel, 2013; Hamid et al., 2013; Jaworska \& Ryan, 2018; Phili \& Ellece, 2013; Riissanen \& Watson, 2014; Yaguchi et al., 2010). However, in Thailand, corpus linguistics is mostly utilized largely to reveal and resolve second language learners' issues 
of vocabulary, grammar, and natural communication. For example, a study by Pitukwong, Soranasathaporn, Thanathiti, and Engchuan (2014) observed that studies on Thai undergrad students' vocabulary learning strategies in English for Specific Purposes (ESP) classes were underrepresented. Similarly, a recent one by Chareonkul and Wijitsopon (2020) detected use of the present perfect tense causing challenges among Thai second language learners.

In addition to issues of vocabulary and grammar, corpus linguistics can be employed to help solve the issues of Thai second language learners' natural communication. For instance, Arya (2021)'s findings clearly showed that discourse markers such as $\mathrm{OK}$, but and so were more useful for interpersonal communication (hedge, or mitigation) and cognitive (formulating and repairing) functions than for referential purpose, so employing these discourse markers in a conversation could help Thai EFL learners produce authentic languages. Wijitsopon (2021) looked into the quantifier laay or หลาย in Thai had a broad meaning: Small, medium, and large quantities, or the plural forms of nouns, with useful implications to Thai EFL learners, translators, and interpreters when expressing its concept in English. More recently, a corpus analysis study was done on LGBT-related discourse revealing underrepresented homosexual identities in English news in Thailand (Chuaikun \& Wijitsopon, 2021).

The beginning of this literature review has shown the known development of movements on women's rights globally. In Thailand, we have seen policy changes such as matrimonial property management, double marital registration, and increase of women's studies programs. Nevertheless, in spite of all policies changed to better serve Thai women to have equal status to men, gender inequality remains one of the greatest challenges (Bui \& Permpoonwiwat, 2015; Chinlumprasert, 2001; Ford \& Kittisuksathit, 1996; Isaraphakdi, 2000; Jarunratanakul \& Jinchang, 2018). Moreover, while corpus linguistics analyses are widely used to reveal gender ideologies elsewhere, little has been done in studies of language and power in Thai context, especially ones being subtle and can go unnoticed. We also argue that to unpack sociocultural issues and ideologies for fuller understanding of power relations, analyses must be conducted in the local native language. The next section will show how we can obtain the answers to the two research questions by 
investigating sections of vision, mission, core values, and about us in girls' school websites.

\section{Methodology}

\section{Corpus Analysis}

Corpus investigations of gender representations in social realities (Phili \& Ellece, 2013; Riissanen \& Watson, 2014; Yaguchi et al., 2010) and power between genders in text books and learning materials (Daniel, 2013; Hamid et al., 2013; Lee, 2018) typically include analytical steps of frequency, collocation, concordance lines, semantic preference, and sematic prosody. The collocational statistics widely used is the mutual information (MI) score of 3.0 or higher to measure the strength of words that typically co-appear (Oakes, 1998). The collocates can also allow a researcher to observe semantic preference, a relation between a searched agent and a group of semantically connected vocabularies (Stubbs, 2001) and semantic prosody (Louw, 1993), an evaluative and attitudinal tone which a word expresses classified as positive or negative meaning. By integrating frequency, collocation (MI scores), semantic preference and prosody in this present study, we reckoned that it will help reveal gender representations in our data more objectively.

While a bigger corpus was considered better in the early 1960s, there was a movement exploring usefulness of a small corpus (Ma, 1993; Tribble, 2002) and the results confirmed that it was just a matter of research purpose and specific questions which a researcher was trying to answer (Flowerdew, 2002). Therefore, there is no ideal size for a corpus and it can range from around 5,000 words (Louw, Watson Todd, \& Jimarkon, 2016), 25,000 words (Cutting, 1999), 34,000 words (Farr \& O'Keeffe, 2002), 52,000 words (Koester, 2006), and up to 250,000 words (Flowerdew, 2004).

Small corpora are particularly useful when it comes to exploring social issues. That is, they allow a closer look at the contexts in where the texts are produced, so this type of analysis is able to reveal the connections between linguistic patterns and contexts of use (O'Keeffe, 2007).

The study corpus consisted of 12,618 words which included the entirety 
of data obtained from all girls' schools in Thailand. Therefore, we argue that our small corpus was specialized for serving the research purpose and answering the research questions.

\section{Tools and Analytical Procedures}

\#LancsBox 6.0 version (Brezina, McEnery \& Wattam 2015) is a concordance software working with any language as long as they have spacing. However, certain features of Thai language - missing of spacing and full-stops - required specific preparation, so Thai Word Segmentation software was utilized to help solve this issue (Aroonmanakun, 2007). \#LancsBox 6.0's features of frequency and collocation tests (MI score) were used in the analysis. The analysis was done using the original Thai texts but the words were later translated for data presentation where English takes priority. The analytical procedure (Baker, 2006) includes deciding the top-frequent searched term followed by listing its collocates (Salahshour, 2016). Then, concordance lines of the searched term were run and its obtained collocates were displayed to see the overall picture of semantic preference and prosody. After that, another MI score was run for clustering collocates which signify ideologies. Finally, ideologies were discussed.

\section{Results}

\section{The Frequency Test}

After a frequency test was conducted, the searched agent learner (ผู้เรียน) appeared in the top list (number 7) in Table 1 and it was selected to be analyzed for the next steps. In fact, two of the searched agents student (นักเรียน) and learner (ผู้รียนน) were found. We combined them and used learner for convenience. However, it was also worth closely looking at other frequent words. Most frequent words have, give, develop, belong, follow, support, and standard seemed to have positive meanings surrounding learner, so learner was located among other top positive 10 frequent words. 


\section{Table 1}

Most Frequent Words from the Corpus

\begin{tabular}{|c|c|c|}
\hline Rank & Word & Frequency \\
\hline 1 & have (มี) & 617 \\
\hline 2 & and (และ) & 578 \\
\hline 3 & NA (การ) & 451 \\
\hline 4 & be (เป็น) & 358 \\
\hline 5 & give (ให้) & 272 \\
\hline 6 & develop (พัฒนา) & 267 \\
\hline 7 & learner (ผู้เรียน) & 258 \\
\hline 8 & school (โรงเรียน) & 244 \\
\hline 9 & at (ที่) & 222 \\
\hline 10 & $\mathrm{NA}$ (ความ) & 222 \\
\hline 11 & in (ใน) & 211 \\
\hline 12 & belong to (ของ) & 186 \\
\hline 13 & follow (ตาม) & 179 \\
\hline 14 & support (ส่งเสริม) & 143 \\
\hline 15 & standard (มาตรฐาน) & 139 \\
\hline
\end{tabular}

\section{The Collocation Test}

Next, after running a collocation test of learner with the MI cut off point at 3.0, the results drawing many function words were found. Only the content words that were found relevant were chosen (Baker, 2006). This was also supported by Matthews and Kotzee (2020) who, in their study, located and selected the most relevant and the strongest collocates beyond $5.0 \mathrm{MI}$ scores for 
analysis of university prospectuses.

The results showed 14 collocates (Table 2), with their MI scores ranging from highest to lowest. This signifies that the 14 collocates were strongly and statistically linked to the word learner.

\section{Table 2}

The Results of Collocation Test of 'Learner' (ผู้เรียน)

\begin{tabular}{|c|c|c|c|c|c|}
\hline \# & MI Score & $\begin{array}{c}\text { Position } \\
\text { (left or right) }\end{array}$ & Collocates & $\begin{array}{l}\text { Freq. } \\
\text { (coll.) }\end{array}$ & $\begin{array}{c}\text { Freq. } \\
\text { (corpus) }\end{array}$ \\
\hline 1 & 5.36 & $\mathrm{R}$ & important (สำคัญ) Adj. & 6 & 7 \\
\hline 2 & 5.00 & L & instill (ปลูกฝัง) V. & 6 & 9 \\
\hline 3 & 4.73 & $\mathrm{R}$ & teacher (ผู้สอน) N. & 5 & 9 \\
\hline 4 & 4.67 & $\mathrm{R}$ & potential (ศักยภาพ) Adj. & 33 & 62 \\
\hline 5 & 4.48 & L & $\operatorname{aim}($ มุ่ง) V. & 14 & 30 \\
\hline 6 & 4.47 & L & identity (อัตลักษณ์) N. & 6 & 13 \\
\hline 7 & 4.44 & $\mathrm{R}$ & allow (ให้) V. & 123 & 272 \\
\hline 8 & 4.19 & $\mathrm{R}$ & skills (ทักษะ) N. & 19 & 50 \\
\hline 9 & 4.07 & L & promote (ส่งเสริม) V. & 50 & 143 \\
\hline 10 & 4.05 & L & develop (พัฒนา) V. & 92 & 267 \\
\hline 11 & 4.00 & L & activity (กิจกรรม) N. & 12 & 36 \\
\hline 12 & 3.93 & L & support (สนับสนุน) V. & 7 & 22 \\
\hline 13 & 3.85 & $\mathrm{R}$ & ethics (จริยธรรม) N. & 12 & 40 \\
\hline 14 & 3.82 & $\mathrm{R}$ & lady (กุลสตรี) N. & 5 & 17 \\
\hline
\end{tabular}

The concordance software \#LancsBox 6.0, apart from the list of collocates in Table 2, provided us with the collocation graph (Figure 1) displaying particular collocation patterns in Table 2 . We can see varying degrees in the 14 words appeared, and were linked with the lexical item 'learner'. 


\section{Figure 1}

Collocation Graph of the Lexical Item 'Learner' (ผู้เรียน)

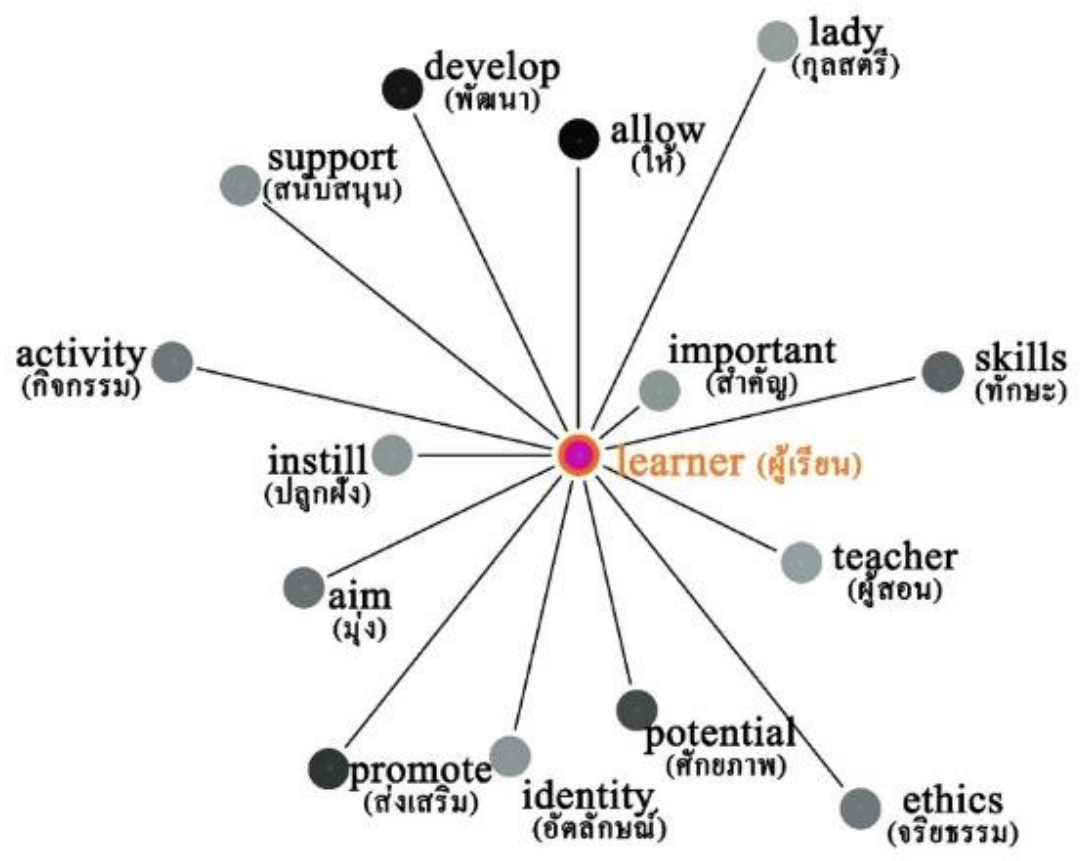

\section{Semantic Preference}

From Figure 1, the position of the collocates can be seen to the left and to the right of the searched agent learner. The collocates: identity, promote, aim, instill, activity, support, and develop are to the left. Meanwhile, the collocates: lady, important, skills, teacher, potential, and ethics are to the right. The only collocate appearing in the middle is allow. Figure 1 bears a particular interesting pattern of collocation. To be more specific, 5 out of the 7 collocates to the left: promote, aim, instill, support, and develop including the one in the middle allows are to do with process, so we can infer that these 6 collocates share roughly a common semantic set of teaching process. Meanwhile, 4 out of the 6 collocates to the right: skills, potential, lady, and ethics appear to be the outcomes of the teaching process. We can easily say that these 4 collocates are common semantic words of outcomes. 
To answer the RQ1: What were the characteristics of Thai girls' lexically prescribed in girl schools' websites? The searched agent learner indicates semantic preferences for teaching process and its outcomes. The semantic preference for the outcomes including skills, potential, lady, and ethics, reveals the desirable characteristics of Thai girls lexically prescribed by Thai schools. Therefore, the semantic preferences of desirable characteristics of Thai girls have answered the research in RQ1.

In relation to the four desirable characteristics: skills, potential, lady, and ethics mentioned above, collocates skills, and potential appeared to be common outcomes which Thai students were taught and expected to possess. Therefore, instead, we paid particular interest in the collocates lady, and ethics to further inquire if they could lead us to explain the construction of ideologies by deconstructing our data into lexical units.

Next, we investigated the construction of Thai female ideologies to obtain the answer for RQ2: What underlying ideologies were constructed in the identities of Thai female adolescents in the discourses? We analyzed the concordance lines between learner and lady, and between learner and ethics. Then, we ran collocation tests of lady and ethics in order to see an overall picture of what underlying ideologies Thai girls were constructed. The following is step-by-step details of the findings.

Semantic prosody: The concordance analysis. Before we conducted another MI score of collocates lady, and ethics, we were examining their overall tone in concordance lines. Table 3 shows concordance lines translated into English accompanied by the original Thai texts. In this table, the top-searched word learner (in the middle of concordance lines) was strongly collocated with lady (bolded). In addition, there were several words (italic) which co-occurred between learner and lady such as the italic potential, world citizen, international standard, quality, efficient, and well-mannered. To us, these words seemed positive, so we inferred that the collocate lady had a positive semantic prosody because it was frequently collocated with positive meanings. The collocate lady shall be discussed further in concordance lines. 
Table 3

Concordance Lines of 'Learner' Surrounded by 'Lady'

\begin{tabular}{|c|c|c|c|}
\hline Index & Left & Node word & Right \\
\hline \multirow[t]{2}{*}{39} & $\begin{array}{l}\text { Thainess. Be ambitious to } \\
\text { learn. Step up to an } \\
\text { international level and for }\end{array}$ & learners & $\begin{array}{l}\text { to be Thai ladies, who have } \\
\text { 'potential' to become a } \\
\text { 'world citizen' }\end{array}$ \\
\hline & ความ เป็น ไทย ใฝ่ เรียนรู้ สู่ สากล & ผู้เรียน & $\begin{array}{l}\text { เป็น กุลสตรี ไทย มี ศักยภาพ เป็น } \\
\text { พลโลก }\end{array}$ \\
\hline \multirow[t]{2}{*}{40} & $\begin{array}{l}\text { World. Promote Thai } \\
\text { ladylikeness. Develop }\end{array}$ & learners & $\begin{array}{l}\text { to have potential to reach } \\
\text { 'international standard', and } \\
\text { to develop }\end{array}$ \\
\hline & $\begin{array}{r}\text { โลก ส่งเสริม ความ เป็น กุลสตรี } \\
\text { ไทย พัฒนา }\end{array}$ & ผู้เรียน & $\begin{array}{l}\text { ให้ มี ศักยภาพ ตาม มาตรฐานสากล } \\
\text { พัฒนา }\end{array}$ \\
\hline \multirow[t]{2}{*}{43} & $\begin{array}{r}\text { increase domestically and } \\
\text { internationally so }\end{array}$ & learners & $\begin{array}{l}\text { can be ladies, to have } \\
\text { characteristics and values } \\
\text { which ... }\end{array}$ \\
\hline & $\begin{array}{l}\text { ทั้ง ภายใน ประเทศ และ } \\
\text { ต่างประเทศ เพิ่ม ขึ้น }\end{array}$ & ผู้เรียน & $\begin{array}{l}\text { เป็น กุลสตรี มี คุณลักษณะ และ } \\
\text { ค่านิยม ที่ }\end{array}$ \\
\hline \multirow[t]{2}{*}{149} & $\begin{array}{r}\text { Setthabutbamphen } \\
\text { School is a 'quality' } \\
\text { organization which aims to } \\
\text { develop }\end{array}$ & learners & $\begin{array}{l}\text { to become modern Thai } \\
\text { ladies who ... }\end{array}$ \\
\hline & $\begin{array}{l}\text { เศรษฐบุตร บำเพ็ญ เป็น องค์กร } \\
\text { คุณภาพ มุ่ง พัฒนา }\end{array}$ & ผู้เรียน & ให้ เป็น กุลสตรี ไทย สมัย นิยม สู่ \\
\hline \multirow[t]{2}{*}{230} & $\begin{array}{r}\text { Foreign languages } \\
\text { 'efficient' and support }\end{array}$ & a learner & $\begin{array}{l}\text { to be a Thai lady and a } \\
\text { 'well-mannered' person } \\
\text { who... }\end{array}$ \\
\hline & $\begin{array}{r}\text { ภาษา ต่างประเทศ ที่ มี ประสิทธิภาพ } \\
\text { ส่งเสริม ให้ }\end{array}$ & ผู้เรียน & เป็น กุลสตรี ไทย และ สุภาพ ชน ที่ \\
\hline
\end{tabular}

Meanwhile, in Table 4 which shows the concordance lines for ethics, the topsearched word learner (in the middle of concordance lines) was also strongly linked to ethics (bolded). Several words (italic) co-occurred with learner and ethics: Conserve, world citizens, standard, potential, and quality. To us, when these co-occurred words were thematically grouped together (Baker, 2006, p. 118), they tended to be more of good qualities and they seem positive as 
well, so we inferred that collocate ethics had a positive semantic prosody because it was frequently collocated with positive meanings.

\section{Table 4}

Concordance Lines of 'Learner' Surrounded by 'Ethics'

\begin{tabular}{|c|c|c|c|}
\hline Index & Left & $\begin{array}{l}\text { Node } \\
\text { word }\end{array}$ & Right \\
\hline \multirow[t]{2}{*}{14} & $\begin{array}{r}\text { reform education in the } \\
\text { century for }\end{array}$ & learners & $\begin{array}{l}\text { to have virtue and ethics } \\
\text { and to gain knowledge and } \\
\text { skills }\end{array}$ \\
\hline & ปฏิรูป การศึกษา ใน ศตวรรษ ที่ เพื่อให้ & ผู้เรียน & $\begin{array}{l}\text { มี คุณธรรม จริยธรรม มี ความรู้ และ } \\
\text { ทักษะ }\end{array}$ \\
\hline \multirow[t]{2}{*}{36} & $\begin{array}{r}\text { to be a part of the society and } \\
\text { community. Support }\end{array}$ & learners & $\begin{array}{l}\text { to cultivate virtue, ethics, } \\
\text { and to 'conserve' Thai } \\
\text { culture }\end{array}$ \\
\hline & ส่วนร่วม ของ สังคม และ ชุมชน ส่งเสริม ให้ & ผู้เรียน & $\begin{array}{l}\text { มี คุณธรรม จริยธรรม และ อนุรักษ์ } \\
\text { วัฒนธรรม ไทย }\end{array}$ \\
\hline
\end{tabular}

Help support learners to be potential 'world citizens' and

for the

75

ร่วม พัฒนา ผู้เรียน มี ศักยภาพ เป็น พลโลก

academic. Moving towards international 'standard'. Instill

80

วิชาการ ก้าว สู่ มาตรฐาน สากล ปลูกฝัง ให้

for a learner to have 'potential'

in order to be a world citizen

87

and for

เพื่อ ให้ ผู้เรียน มี ศักยภาพ เป็น

พลโลก

Learning virtue and ethics so

that the

112

การ เรียนรู้ อย่าง มี คุณธรรม และ จริยธรรม learners to cultivate virtue, ethics, values, and characteristics which ...

มี คุณธรรม จริยธรรม ค่านิยม และ คุณลักษณะ อัน

learners to cultivate virtue, ethics, and characteristics which ...

ผู้เรียน มี คุณธรรม จริยธรรม และ คุณลักษณะ อัน พึง

a learner to cultivate virtue and ethics

ผู้เรียน มี คุณธรรม จริยธรรม และ คุณลักษณะ อัน พึง

Learners develop their 'potential' towards

ผู้เรียน ได้รับ การ พัฒนา เต็ม ศักยภาพ สู่ การ
Thai ethics. Educational management for learners to develop virtue, ethics, 'quality' according to standards 


\begin{tabular}{|c|c|c|c|}
\hline Index & Left & $\begin{array}{l}\text { Node } \\
\text { word }\end{array}$ & Right \\
\hline & จริยธรรม ตาม วิถี ไทย จัดการ ศึกษา ให้ & ผู้เรียน & $\begin{array}{l}\text { มี คุณธรรม จริยธรรม มี คุณภาพ ตาม } \\
\text { มาตรฐาน }\end{array}$ \\
\hline \multirow[t]{2}{*}{154} & $\begin{array}{r}\text { good governance. Learners } \\
\text { possess desirable 'qualities' } \\
\text { according to international } \\
\text { standards and for }\end{array}$ & learners & $\begin{array}{l}\text { to cultivate virtue, ethics, } \\
\text { and values }\end{array}$ \\
\hline & $\begin{array}{r}\text { ธรรมาภิบาล ผู้เรียน มี คุณภาพ ตาม มาตรฐาน } \\
\text { สากล }\end{array}$ & ผู้เรียน & $\begin{array}{l}\text { มี คุณธรรม จริยธรรม ค่านิยม หลัก ของ } \\
\text { คน }\end{array}$ \\
\hline \multirow[t]{2}{*}{168} & $\begin{array}{l}\text { well-being. Learners have } \\
\text { 'aesthetic experiences'. }\end{array}$ & Learners & $\begin{array}{l}\text { will have virtue, ethics, } \\
\text { and characteristics which ... }\end{array}$ \\
\hline & สุข ภาวะ ที่ ดี และ มี สุนทรียภาพ & ผู้เรียน & มี คุณธรรม จริยธรรม และ ค่านิยม ที่ พึง \\
\hline \multirow{2}{*}{178} & $\begin{array}{r}\text { step up to an international } \\
\text { 'standard' so }\end{array}$ & learners & $\begin{array}{l}\text { will have virtue and ethics, } \\
\text { and characteristics which ... }\end{array}$ \\
\hline & ยก ระดับ สู่ ความ เป็น มาตรฐาน สากล & ผู้เรียน & $\begin{array}{l}\text { มี คุณธรรม จริยธรรม และ คุณลักษณะ ที่ } \\
\text { พึง }\end{array}$ \\
\hline \multirow[t]{2}{*}{220} & $\begin{array}{r}\text { well-being and learners have } \\
\text { 'aesthetic } \\
\text { experiences' so that }\end{array}$ & learners & $\begin{array}{l}\text { can have virtue and } \\
\text { ethics, and characteristics } \\
\text { which ... }\end{array}$ \\
\hline & ที่ ดี และ มี สุนทรียภาพ ปลูกฝัง ให้ & ผู้เรียน & $\begin{array}{l}\text { มี คุณธรรม จริยธรรม และ คุณลักษณะ } \\
\text { อัน พึง }\end{array}$ \\
\hline \multirow{2}{*}{254} & $\begin{array}{r}\text { 'academic' and virtue and } \\
\text { ethics for }\end{array}$ & Learners & $\begin{array}{l}\text { at Ampornpaisarn School } \\
\text { can realise that }\end{array}$ \\
\hline & $\begin{array}{r}\text { ด้าน วิชาการ และ ด้าน คุณธรรม จริยธรรม } \\
\text { สำหรับ }\end{array}$ & ผู้เรียน & อัมพร ไพศาล พึง รู้จัก กล่าว คำ ว่า \\
\hline
\end{tabular}

Now we know that collocates lady and ethics are of positive semantic prosody because several positive words co-occur among them (See Tables 3 and 4). For example, the collocate lady was surrounded by words such as potential, world citizen, international standard, quality, efficient, and well-mannered. The collocate ethics was surrounded by words such as, conserve, world citizen, standard, and potential.

Next, we further conducted another collocation test series with the MI score for lady, and ethics. Figure 2 shows the collocation networks of lady, and ethics. 


\section{Figure 2}

Collocates of Lady (กุลสตรี) and Ethics (จริยธรรม) with MI Scores

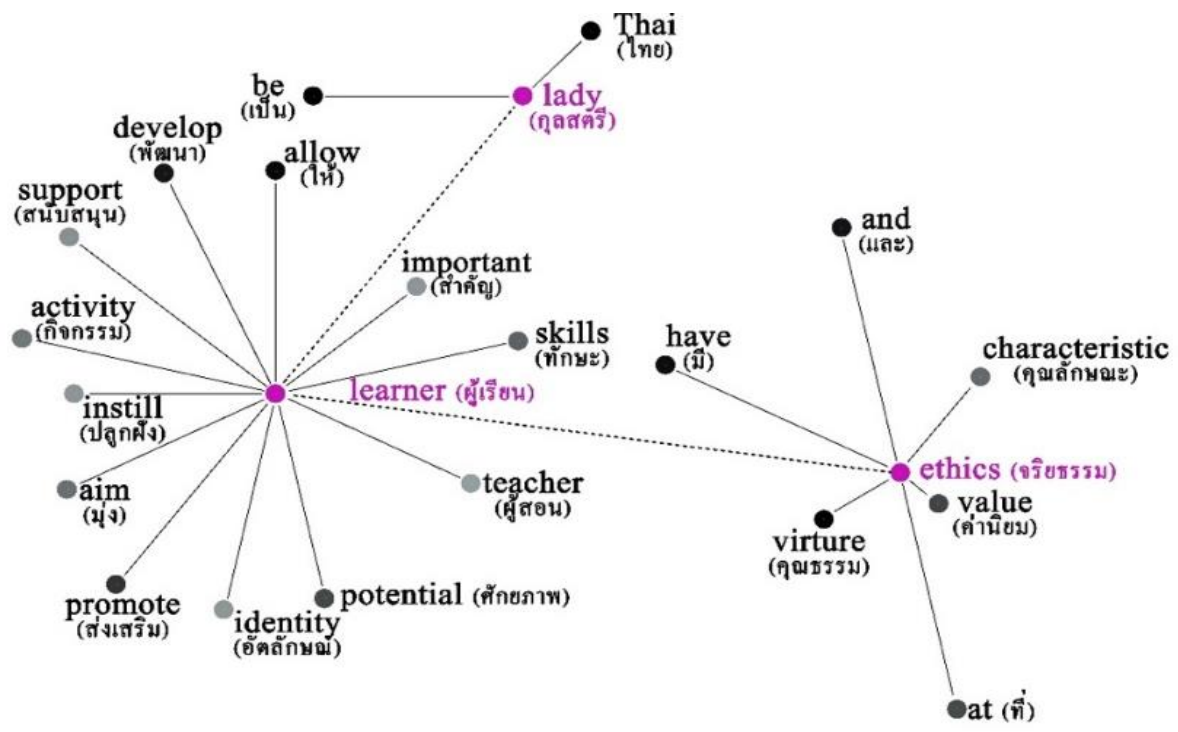

After conducting another collocation test series at MI score of lady, and ethics, Tables 5 and 6 below show more collocates of lady, and ethics.

In Table 5, the collocate lady is significantly associated with the collocate Thai which had the highest MI score at 6.80 and the highest frequency at 14 . The MI score of 6.80 indicates the high association between the two lexical items - lady and Thai, where 14 is considered to be highly frequent.

\section{Table 5}

Collocates of 'Lady' (กุลสตรี)

\begin{tabular}{clcc}
\hline Position & Collocate & MI score & Frequency (Coll.) \\
\hline $\mathrm{R}$ & Thai (ไทย) & 6.80 & 14 \\
$\mathrm{~L}$ & be (เป็น) & 4.85 & 14 \\
$\mathrm{~L}$ & learner (ผู้เรียน) & 3.84 & 5 \\
\hline
\end{tabular}

In Table 6, the collocate ethics (จริยธรรม) is strongly linked to virtue (คุณธรรม) with 
the highest MI score at 6.91 and the frequency of 38. The MI score 6.91 indicates the highest value of strength. Meanwhile, the frequency value of 38 is also the highest in frequency.

\section{Table 6}

Collocates of 'Ethics' (จริยธรรม)

\begin{tabular}{clcc}
\hline Position & \multicolumn{1}{c}{ Collocate } & MI score & Frequency (Coll.) \\
\hline L & virtue (คุณธรรม) & 6.91 & 38 \\
$\mathrm{~L}$ & have (มี) & 3.98 & 31 \\
$\mathrm{R}$ & and (และ) & 3.92 & 28 \\
$\mathrm{R}$ & value (ค่านิยม) & 7.60 & 13 \\
$\mathrm{R}$ & at (ที่) & 4.08 & 12 \\
$\mathrm{~L}$ & learner (ผู้เรียน) & 3.87 & 12 \\
$\mathrm{R}$ & characteristic (คุณลักษณะ) & 6.24 & 7 \\
\hline
\end{tabular}

In short, according to Figure 1 (to the left of learner), the learners were aimed, allowed, instilled, promoted, developed, and supported:

1) to be a lady in the Thai way or we can say a ladylike Thai; and

2) to uphold ethics along with virtue.

It is evidential that the websites of Thai girls' schools communicate that traits of being a ladylike Thai with ethical code and virtue are important qualities in their education. Ethics together with virtue are an honesty trait in Thai language (Na Nakorn, 2019). Therefore, this can be inferred that Thai girls are formed to be ladylike and to have honesty as their desirable qualities. Interestingly, this result is in line with Anderson and Grace (2018)'s study which revealed how Cambodian girls and women were ideologically constructed to be 'ladylike' and 'honest' with their husbands. To be more specific, the authors investigated Cambodian education policy, using policy discourse 
analysis as a tool, and found that this education policy used a poem Chbab Srey (Code of Conduct for Women) to be taught in secondary schools. The study concluded that the poem expected Cambodian women; for example, to be ladylike by walking quietly and talking softly and to be honest with their husbands by staying at home, worshiping their husbands, and remaining silent when it came to any doubts towards their husbands. The following parts of discussion regarding intertextuality will answer RQ2: What underlying ideologies were constructed in the identities of Thai female adolescents in the discourses? as we have just shown the underlying ideologies constructed in our dataset.

\section{Discussion}

Intertextuality is the association across texts which are shaped by what has come before it (Kristeva, 1980). The fact that Thai female students are ideologically constructed to be Thai ladylike and to have honesty quality reminds us of the Thai ideal women portrayed as proper women in the most famous Thai novel, Four Reigns. The leading character, 'Mae Phloi', born circa 1882 , is an ideal Thai woman born in a rural community, but raised in a Thai Royal Palace. Finally, she is arranged to marry a Thai man who has a good education and career.

Mae Phloi behaves humbly and properly, takes care of her family well, and remains honest with her husband (Pramoj, 1998). Four Reigns reflects Thai traditional and cultural realities how Thai women should behave. In this novel, she does not have any education like her husband because Thai education, at its start, took place at Thai temples where boys were required to study in order to become monks. Rather, they were trained to behave properly, and to become skilled at housekeeping and cooking at home or the royal courts (Hays, 2014). This was an ideal pathway which all Thai girls must have gone through to become good wives and caring mothers in the future (Jordan, 1991). We believe that this novel reflects being Thai ladylike in Thai society. Nevertheless, we ask further questions that have been addressed by such studies as Abdi and Basarati (2018), Baker and Pasuk (2005), and Lavrusheva (2013). 
1. How are Thai female students represented in this dataset?

2. How are such discourses legitimated?

3. Who benefits from these legitimated discourses?

The followings are the answers to the three questions.

\section{Benevolent Sexism}

The qualities of being Thai ladylike and having honesty are found in the texts on the websites of Thai girls' schools to represent desirable characteristics of females. To be precise, the two concepts view Thai women to be naturally caring housewives who need protection from. These views seem well-intended and positive, but in fact, it infers that Thai women are weak and needs men's protection. Further, it seems to limit their ability to have equal status and rights to Thai men and to go on and have an advanced career. This subtle bias constructs a damaging stereotype, so this is called 'Benevolent Sexism' (Glick \& Fiske, 1996).

Therefore, to answer the additional three questions above, it seems that Thai female students are represented in this data as 'Mae Phloi' (mentioned in a section of intertextuality) with said characteristics that are Thai by having loyalty to her man. Although presently in the 21st century, Thai female students are still being instilled with these kinds of ideologies and it seems that these ideologies are legitimated in Thai society. Lastly, who benefits from these legitimated discourses? The following section has the answer to this.

\section{Benevolent Sexism in Thailand}

In Thailand, manipulative and discriminatory discourses on gender and sex are common to witness. This is one of the more damaging discriminatory practice against women than the aforementioned ones because it is subtle and operates on positive reinforcement. They come from different and powerful forms which either force or persuade Thai people as good things do. For example: 1) Thai 
women's gendered and sexual subjectivities (Muecke, 2004); and 2) Maintenance of patriarchy by male dominance (Persaud, 2005). The followings elaborate these examples of different and powerful forms.

The first example concerns with women's gendered and sexual subjectivities. Thai women are portrayed and known by international yet discriminatory discourses that they are associated with prostitution (Muecke, 2004). Thaweesit (2004) reveals that Thai women are locally known as good people because they are supposed to be loyal to one man, and must take care of their husband and children well in terms of domestic help. Thai women's sex experience is strongly influenced by Thai traditional discourse of gender and sexuality. If they left their husband for another man for whatever reasons, they would be condemned by society. This is a set of ideological discourses that a good woman must remain married until death although there might be domestic violence caused by men. Interestingly, the result of this present study also supports the study by Thaweesit (2014) that Thai female students should be constructed to be honest in future marriages according to Thai tradition. If they were not, they would be judged by society. Therefore, being honest in terms of staying faithful to one man while taking care of the household are beliefs which force Thai people, particularly Thai women, to adopt as a virtuous quality.

Persaud (2005) points out that patriarchy is well-promoted in Thailand. The examples are tourist promotion materials such as brochures and leaflets from Thai Airways International which invite foreign tourists to visit Thailand. The images on the brochures and leaflets portray white Western males and white-collar travelers receiving special attention given by Thai female flight attendants who are dressed with Thai national costume and bowing to the travelers. Not surprisingly, the ideology Thai ladylike found in this present study is also in line with the study by Persaud (2005) because Thai female students are taught and instilled to have well-behaved manners according to Thai traditions.

Our results are in line with Thaweesit (2014) and Persaud (2005)'s research results and with several others (Bui \& Permpoonwiwat, 2015; Chinlumprasert, 2001; Ford \& Kittisuksathit, 1996; Isaraphakdi, 2000; Jarunratanakul \& Jinchang, 2018). Being constructed in girls' schools as 
ladylike and instilled to be honest in marriage; as a result, Thai women have been voiceless, sensitive, and indecisive at work. In addition, they have been passive or submissive when it comes to dating partners and their own sexual desire. Further, they have been automatically assumed to be obedient and honest when it comes to marriage and parenting. These assumed qualities upon Thai women can be one of the main causes as to why they still experience benevolent sexism.

\section{Conclusion}

On their websites, Thai girls' schools represent their institutions as a place where girls not only receive knowledge, but are also trained to be 'ladylike' and 'proper ladies' and to possess the quality of 'honesty'. However, from the lens of modern-day education, education is meant to benefit a learner's intellectual and physical development, self-realization, and social and political values (Firdaus \& Mariyat, 2017). The two qualities of being a ladylike Thai and honesty emerged from our corpus analysis was an alarming discovery as it also implies that this education formed by the cultures and traditions purposefully prevents Thai girls from experiencing equal rights and opportunities as boys. It aims at framing Thai girls to be well-mannered, obedient, submissive women, and, one day in the future, good wives and mothers. This view, if it goes unnoticed, seem well-intended and positive but it infers that girls are sensitive and weak. Further, it tends to limit Thai girls from having equal status and rights and pursuing a better career as they are bound to end up in the family kitchen, at the end of the day. Our findings have informed us that benevolent sexism is in operation in broad daylight. Positive claims such as being ladylike and proper ladies are used to justify the status quo in which women are objectified and defined by their roles approvable by society. These claims are as harmful to women, young or not, as insulting.

These are causes as to why Thai women still experience subtle discrimination despite all the policies reformed for Thai women mentioned in the literature review. Discourses engrained with this notion increase women's positive emotions so they work in disguise (Becker \& Wright, 2011). We see that this can be harmful to women's wellbeing because without realizing it, they will be the ones who maintain this inequality in chivalry. 


\section{Limitations and Recommendations}

Our corpus may be considered $(12,618$ words) small in size because, in each girls' school website, there were limited words in the sections chosen as our data. This could be compensated by the fact that our data came from all girls' schools in Thailand. In addition, the study results may not be generalizable, but it can be a starting point to go for further studies to see other forces or factors instilling sexism in the area of education. For example, investigations of school teaching materials, classroom discourses and curricula of teacher training programs may be of future interest.

Regarding the methods employed, the MI score can be a sensitive tool to a relatively small size corpus but the results obtained from MI score allowed us to answer the research questions objectively. To be specific, our second research question could be answered by displaying the content words showing desirable and ideological characteristics of girls. For future research with a small size corpus and wish, the MI3 score, instead of MI score, may be more useful because the MI3 will draw both frequent words and content words at the same time (Brezina et al., 2015). Through this method, potential researchers can see both type of lexis and can go further to answer different types of research questions.

\section{References}

Abdi, R., \& Basarati, A. (2018). Legitimation in discourse and communication revisited: A critical view towards legitimizing identities in communication. International Journal of Society, Culture \& Language, 6(1), 86-100.

Aroonmanakun, W. (2007, December 13-15). Thoughts on word and sentence segmentation in Thai. Seventh Symposium on Natural language Processing 2007, Pattaya, Thailand.

Anderson, E. \& Grace, K. (2018). From schoolgirls to "virtuous" Khmer women: Interrogating Chbab Srey and gender in Cambodian education policy. Studies in Social Justice, 12(2), 215-234. https://doi.org/10.26522/ssj.v12i2.1626 
Arya, T. (2020). Exploring discourse marker use in Thai university students' conversations. LEARN, 13(1), 247-267.

Athamneh, S., \& Benjamin, O. (2019). Education as weapon: Poverty and school for Palestinian adolescent girls living in Israel. Gender and Education, 33(2), 235-251. https://doi.org/10.1080/09540253.2019.1685655

Ault, M. K., Ness, A. M., Taylor, W. D., Johnson, G., Connelly, S., Jensen, M. L., \& Dunbar, N. E. (2017). Ideological lens matters: Credibility heuristics, pre-existing attitudes, and reactions to messages on ideological websites. Computers in Human Behavior, 68, 315-325. https://doi.org/10.1016/j.chb.2016.11.053

Chris, B., \& Pasuk, P. (2005). A history of Thailand. Cambridge University Press.

Baker, P. (2006). Using corpora in discourse analysis. Continuum.

Becker, J. C., \& Wright, S. C. (2011). Yet another dark side of chivalry: Benevolent sexism undermines and hostile sexism motivates collective action for social change. Journal of Personality and Social Psychology, 101(1), 62-77. https://doi.org/10.1037/a0022615

Bingöl, D., Şener, İ., \& Çevik, E. (2013). The effect of organizational culture on organizational image and identity: Evidence from a pharmaceutical company. Procedia-Social and Behavioral Sciences, 99, 222-229. https://doi.org/10.1016/j.sbspro.2013.10.489

Brezina, V., McEnery, T., \& Wattam, S. (2015). Collocations in context: A new perspective on collocation networks. International Journal of Corpus Linguistics, 20(2), 139-173. https://doi.org/10.1075/ijcl.20.2.01bre

Bui, M.-T. T., \& Permpoonwiwat, C. K. (2015). Gender wage inequality in Thailand: A sectoral perspective. The Journal of Behavioral Science, 10(2), 19-36. https://doi.org/10.14456/ijbs.2015.40

Chareonkul, C., \& Wijitsopon, R. (2020). The English present perfect in authentic use and textbooks: A corpus-driven study. PASAA, 60, 275308.

Chinlumprasert, N. (2001). Date rape perceptions of Thai university students. AU Journal of Technology, 5(1), 37-58.

Chuaikun, D., \& Wijitsopon, R. (2021). A corpus-based study of LGBT-related 
news discourse in Thailand's and international English-language newspapers. Applied Linguistics Review. https://doi.org/10.1515/applirev-2021-0036

Costa, L. (1997). Exploring the history of women's education and activism in Thailand. A Journal of the Southeast Asian Studies Student Association, $1(2)$.

Cutting, J. E. (1999). The grammar of the in-group code. Applied Linguistics, 20(2), 179-202. https://doi.org/10.1093/applin/20.2.179

Daniel, I. O. A. (2013). Language as a power positioning tool: National open university of Nigeria (noun) English course materials as genderised examples. Journal on English Language Teaching, 3(3), 7-15. https://doi.org/10.26634/jelt.3.3.2415

Farr, F. \& O'Keeffe, A. (2002). Would as a hedging device in an Irish context. In R. Reppen, S. M. Fitzmaurice, \& D. Biber (Eds.), Using Corpora to Explore Linguistic Variation (pp. 25-48). John Benjamin Publishing Company. https://doi.org/10.1075/scl.9.04far

Firdaus, F. A., \& Mariyat, A. (2017). Humanistic approach in education according to Paulo Freire. At-Ta'dib, 12(2), 25-48. https://doi.org/10.21111/at-tadib.v12i2.1264

Ford, N., \& Kittisuksathit, S. (1996). Youth sexuality: The sexual awareness, lifestyles and related-health service needs of young, single factory workers in Thailand. Institute for Population and Social Research.

Glick, P., \& Fiske, S. T. (1996). The ambivalent sexism inventory: Differentiating hostile and benevolent sexism. Journal of Personality and Social Psychology, 70(3), 491-512. https://doi.org/10.1037/0022-3514.70.3.491

Hackett, S., Parmanto, B., \& Zeng, X. (2005). A retrospective look at website accessibility over time. Behaviour \& Information Technology, 24(6), 407-417. https://doi.org/10.1080/01449290500066661

Hamid, B. A., Keong, Y. C., Othman, Z., Subakir, M., Yasin, M., \& Baharuddin, J. H. (2013). A corpus-based investigation of gender stereotyping and linguistic sexism in Qatari primary school science textbooks. Pertranika Journal of Social Science and Humanities, 21, 197-218. 
Hawkins, M. \& Norton, B. (2009). Critical language teacher education. In A. Burns, \& J. Richards (Eds.), Cambridge guide to second language teacher education (pp. 30-39). Cambridge University Press.

Hays, J. (2014). Thailand. Facts and Details. http://factsanddetails.com/southeast-asia/Thailand

Isaraphakdi, P. (2000). Sexual attitudes and experience of rural Thai youth. Institute for Population and Social Research.

Jarunratanakul, P., \& Jinchang, K. (2018). Does sexism affect Thai women's psychological and behavioural responses? The stereotype threatbuffering effect of mindfulness. Journal of Pacific Rim Psychology, 12. https://doi.org/10.1017/prp.2018.10

Jaworska, S., \& Ryan, K. (2018). Gender and the language of pain in chronic and terminal illness: A corpus-based discourse analysis of patients' narratives. Social Science \& Medicine, 215, 107-114. https://doi.org/10.1016/j.socscimed.2018.09.002

Jimenez, E., Lockheed, M., \& Wattanawaha, N. (1988). The relative efficiency of private and public schools: The case of Thailand. The World Bank Economic

Review,

$2(2)$, 139-164. https://doi.org/10.1093/wber/2.2.139

Jimenez, E., Lockheed, M. E., \& Mundial, B. (1988). The relative effectiveness of single-sex and coeducational schools in Thailand. International Bank for Reconstruction and Development.

Kaptein, M. (1998). Ethics management. In K. Muel (Ed.), Ethics Management (pp. 31-45). Springer.

Konner, M. (2012, October 1). Misogyny, chauvinism, sexism, or what? Psychology Today. https://www.psychologytoday.com/us/blog/thetangled-wing/201210/misogyny-chauvinism-sexism-or-what

Kristeva, J. (1980). Desire in language: A semiotic approach to literature and art. Columbia University Press.

Lavrusheva, O. (2013). Discursive legitimation strategies in the media. Case study of the UK retail planning policy [Master Thesis, Aalto University]. https://aaltodoc2.org.aalto.fi/bitstream/handle/123456789/12749/hs e_ethesis_13528.pdf?sequence $=1$ \&isAllowed $=y$

Lee, J. F. (2018). Gender representation in Japanese EFL textbooks: A corpus 
study. Gender and Education, 30(3), 379-395. https://doi.org/10.1080/09540253.2016.1214690

Louw, B. (1993). Irony in the text or insincerity in the writer? The diagnostic potential of semantic prosodies. In M. Baker, G. Francis, \& E. TogniniBonelli (Eds.), Text and technology (pp. 157-176). John Benjamins Publishing Company.

Louw, S., Watson Todd, R., \& Jimarkon, P. (2016). Teacher trainers' beliefs about feedback on teaching practice: Negotiating the tensions between authoritativeness and dialogic space. Applied Linguistics, 37(6), 745764.

Lynne, F. (2002). Corpus-based analysis in AEP. In F. John (Ed.), Academic Discourse (pp. 95-114). Routledge.

Flowerdew, L. (2004). The argument for using English specialized corpora to understand academic and professional language. In U. Connor, \& T. A. Upton (Eds.), Discourse in the professions: Perspectives from corpus linguistics. John Benjamins Publishing Company. https://doi.org/10.1075/scl.16.02flo

Ma, B. K C. (1993). Small-corpora concordancing in ESL teaching and learning. Hong Kong Papers in Linguistics and Language Teaching, 16, 11-30.

Matthews, A., \& Kotzee, B. (2020). UK university part-time higher education: A corpus-assisted discourse analysis of undergraduate prospectuses. Higher Education Research \& Development, 1-16. https://doi.org/10.1080/07294360.2020.1713730

Mills, S., \& Mullany, L. (2011). Language, gender and feminism: Theory, methodology and practice. Routledge. https://doi.org/10.4324/9780203814666

Muecke, M. (2004). Guest Editorial: Shifting sexuality among lowland Thai women. Culture, health \& sexuality, 6(3), 183-187. https://doi.org/10.1080/13691050410001680555

Na Nakorn, P. (2019). Virtue and ethics (N. Satienchayakorn, Trans.). Office of the Civil Service Commission [Original work published 2012].

Oakes, M. P. (1998). Statistics for corpus linguistics. Edinburgh University Press.

O'Keeffe, A. (2007, July). The pragmatics of corpus linguistics. The Fourth 
Corpus Linguistics Conference 2007, Birmingham, United Kingdoms.

Onozawa, N. (2001). Thai women: Changing status and roles during the course of Thai modernization. Bulletin of Tokyo Kasei Gakuin Tsukuba Women's University, 5, 81-99.

Papulova, Z. (2014). The significance of vision and mission development for enterprises in Slovak Republic. Journal of Economics, Business and Management, 2(1), 12-16. https://doi.org/10.7763/JOEBM.2014.V2.90

Persaud, W. H. (2005). Gender, race and global modernity: A perspective from Thailand. Globalizations, 2(2), 210-227. https://doi.org/10.1080/14747730500202214

Pitukwong, K., Soranasathaporn, S., Thanathiti, T., \& Engchuan, K. (2014). An investigation of vocabulary learning strategies employed by high and low English proficiency students based on selected vocabulary from a business corpus. Asian International Journal of Social Sciences, 14(1), 106-119. https://doi.org/10.29139/aijss.20140106

Phili, C., \& Ellece, S. E. (2013). Women in the news: Representations of women in the Sunday Standard newspaper in Botswana-A linguistic perspective. PULA: Botswana Journal of African Studies, 27(2), 218236.

Prabjandee, D. (2014). Journey to becoming a Thai-English teacher: New perspective on investigating teacher attrition. Alberta Journal of Educational Research, 60(3), 522-537.

Pramoj, K. (1998). Four Reigns. Silkworm Books.

Rampton, M. (2015, October 25). Four waves of feminism. Pacificu. https://www.pacificu.edu/magazine/four-waves-feminism

Regoli, N. (2019, April 30). 19 advantages and disadvantages of mixed gender schools. Connect Us. https://connectusfund.org/6-advantages-anddisadvantages-of-mixed-gender-schools

Riissanen, A., \& Watson, G. (2014). Gender difference in the use of thought representation: A corpus-based study. English Language Teaching, 7(3), 71-84. https://doi.org/10.5539/elt.v7n3p71

Robkob, R. (2008). A study of the evolution of women's roles in Thai higher education institutions. International Forum of Teaching and Studies, 
9(1), 39-45.

Romanow, L. (2012). The women of Thailand. Global Majority E-Journal, 3(1), 44-60.

Ruvio, A., Rosenblatt, Z., \& Hertz-Lazarowitz, R. (2010). Entrepreneurial leadership vision in nonprofit VS. for-profit organizations. The Leadership Quarterly, 21(1), 144-158. https://doi.org/10.1016/j.leaqua.2009.10.011

Salahshour, N. (2016). Liquid metaphors as positive evaluations: A corpusassisted discourse analysis of the representation of migrants in a daily New Zealand newspaper. Discourse, Context \& Media, 13, 73-81. https://doi.org/10.1016/j.dcm.2016.07.002

Slattery, P., Finnegan, P., \& Vidgen, R. (2019). Creating compassion: How volunteering websites encourage prosocial behaviour. Information and Organization, 29(1), 57-76. https://doi.org/10.1016/j.infoandorg.2019.02.001

Somswasdi, V. (2003). Women's studies in Thailand. The UNESCO Conference on Women's Studies in Asia, Bangkok, Thailand.

Stubbs, M. (2001). Words and phrases: Corpus studies of lexical semantics. Blackwell Publishers.

Tantiwiramanond, D., \& Pandey, S. R. (2008). Does advocacy matter? Women's advocacy campaigns in Thailand. Friedrich-Ebert-Stiftung (FES). http://library.fes.de/pdf-files/bueros/thailand/07042.pdf

Thaweesit, S. (2004). The fluidity of Thai women's gendered and sexual subjectivities. Culture, Health \& Sexuality, 6(3), 205-219. https://doi.org/10.1080/1369105031000156360

Tyson, L. (2014). Critical theory today: A user-friendly guide. Routledge.

Wijitsopon, R. (2021). A corpus-based study of Thai and English quantity word equivalents: Laay, several and many. REFLections, 28(2), 188-207.

Yaguchi, M., Iyeiri, Y., \& Baba, Y. (2010). Speech style and gender distinctions in the use of very and real/really: An analysis of the Corpus of Spoken professional American English. Journal of Pragmatics, 42(3), 585-597. https://doi.org/10.1016/j.pragma.2009.08.002 
Natakorn Satienchayakorn

Tamasato universitetas, Tailandas

natakorn.s@arts.tu.ac.th

\section{Pattamawan Jimarkon}

Stavangerio universitetas, Norvegija

pattamawan.jimarkon@uis.no

\section{MOTERIŠKUMO DISKURSO DEKONSTRAVIMAS: TAILANDO MERGAIČIU MOKYKLU ATVEJIS}

Santrauka. Tyrime analizuojama, kaip Tailando mergaičiu mokyklu interneto svetainèse kuriamos moteriškumo ideologijos ir kaip šios ideologijos dekonstruojamos leksikos lygmenyje. Tyrimo tikslas - ideologiniai isitikinimai, grindžiami merginu ugdymo papročiais taju kultūros kontekste. Ypač daug dèmesio skirta apžvelgti, kaip mokyklos savo interneto svetainiu skiltyse Vizija, Misija, Pagrindinès vertybès bei Apie mus perduoda svarbiausius pranešimus, ir atlikta tekstynu paremta diskurso duomenu analizè. Dažnio ir žodžiu jungimo darbiniu tyrimu išvados atskleide diskurse sukurtas moteriškumo savybes, šlovino paklusnuma, paklusima ir moteriškas savybes. Tyrimas atskleidžia, jog geranoriškas seksizmas švietimo institucijose yra akivaizdi ir dažna kultūrinè praktika.

Pagrindinès sąvokos: tekstyno tyrimas; švietimas; lytis; seksizmas. 